\title{
INOVASI TEKNOLOGI PENERAPAN KOMPOS BLOTONG UNTUK PERBAIKAN KESUBURAN TANAH DAN PENINGKATAN PRODUKTIVITAS TANAMAN TEBU
}

\section{(Innovation Technology of Blotong Compos to Repair Soil Fertility and Increasing Plant Sugarcane Productivity)}

\author{
Muh Afif Juradi ${ }^{1)}$, Edi Tando ${ }^{2)}$ dan Saida $^{3)}$ \\ ${ }^{1)}$ Balai Pengkajian Teknologi Pertanian Sulawesi Tengah \\ ${ }^{2)}$ Balai Pengkajian Teknologi Pertanian Sulawesi Tenggara \\ ${ }^{3}$ Dosen Universitas Muslim Indonesia, Makassar \\ ${ }^{1)}$ Email:afif.juradi@gmail.com \\ ${ }^{3)}$ Email : saida.saida@umi.ac.id
}

\begin{abstract}
Sugarcane (Saccharum officinarum L.) is a variety of sources of carbohydrate as sugar production. Planting of sugar cane monoculture and continuously in dryland causes degradation of soil fertility. One effort to improve soil fertility is the addition of organic matter through the use of Blotong compost. The purpose of this paper is to provide information on blotong compost technology innovation in improving soil fertility and increasing sugarcane productivity. Blotong has potential as a source of organic material from the residual waste from sugarcane crop yields. The macro and micronutrient content of compost in blotong compost play an important role in supporting plant growth. Blotong compost application in the long term can increase the physical, biological and chemical fertility of degraded land. Blotong compost application with inorganic fertilizer can reduce the use of inorganic fertilizer. Blotong application can increase the nutrient content of $N, P$, and microelements in the soil and can increase the growth and productivity plant sugarcane.
\end{abstract}

Keywords: compost; fertility; sugar cane; food security

\section{PENDAHULUAN}

Tebu (Saccharum officinarum L.) ialah jenis tanaman sumber karbohidrat sebagai penghasil gula dan kebutuhannya mengalami peningkatan seiring dengan pertambahan jumlah penduduk (Putri et.al., 2013). Tanaman tebu yang ditanam terus menerus secara monokultur di lahan kering menyebabkan degradasi kesuburan tanah. Kesuburan tanah telah mengalami penurunan di banyak lokasi perkebunan tebu. Hal ini disebabkan oleh pemupukan yang tidak tepat yang telah dilakukan dalam waktu lama. Pemupukan yang biasanya dilakukan hanya pupuk anorganik tanpa penambahan bahan organik. Dengan demikian diperlukan pemberian pupuk yang berimbang berdasarkan hasil uji tanah dan kebutuhan tanaman tebu.

Teknik budidaya tanaman tebu yang tidak memperhatikan aspek ekologi seperti pembakaran sisa panen di lahan pertanaman tebu dapat menyebabkan bakteri dekomposer mati. Selain itu tidak 
dilakukan pengembalian serasah/sisa perkembangan tanaman tebu sehingga panen menyebabkan semakin menurunnya dapat meningkatkan hasil dan rendemen.

kadar bahan organik tanah. Permasalahan Kompos blotong sangat diperlukan tersebut menyebabkan kesuburan tanah karena kebutuhan bahan organik untuk semakin menurun. Untuk dapat mengelola pemupukan tanaman belum terpenuhi kesuburan tanah dengan baik maka harus meskipun sudah tersedia pupuk yang lain. meninggalkan kebiasaan buruk tersebut. Masalah yang dihadapi petani saat ini Disamping itu, pengelolaan hara dalam adalah harga pupuk kimia yang mahal bila perkebunan tebu harus ditujukan untuk musim tanam tiba. Disamping itu keberlanjutan. Pola pengelolaan hara pemakaian pupuk kimia yang terus didasarkan pada realita bahwa menerus membuat tanah menjadi keras pengelolaan hara tidak lagi hanya dan tandus, mikroorganisme dan cacing berorientasi pada target hasil tebu, tetapi tanah hilang, sehingga mengganggu harus diorientasikan pada keberlanjutan. keseimbangan ekosistem (Yuliai dan Salah satu usaha untuk Nugraheni, 2010).

meningkatkan kesuburan tanah adalah Terdapat beberapa faktor yang dengan penambahan bahan organik. mendorong diperlukannya kompos Peningkatan bahan organik dapat blotong sebagai pupuk organik, antara lain dilakukan dengan cara memanfaatkan kesulitan memperoleh pupuk kandang kompos blotong. Tanah yang memiliki matang dalam jumlah besar, adanya kadar bahan organik optimum dapat kendala dalam pemupukan hijau karena meningkatkan kesuburan tanah. Kompos blotong dapat dimanfaatkan karena dapat memperbaiki sifat fisik, kimia dan biologi tanah. Dengan memanfaatkan blotong keterbatasan waktu dan tanah untuk ditanami tanaman penghasil pupuk hijau.

Selama ini blotong belum dimanfaatkan dengan baik dalam bidang untuk bahan organik maka dapat pertanian. Banyak permasalahan yang meningkatkan kesuburan tanah yang menyebabkan, misalnya sulitnya proses berlanjut. Kompos blotong yang pengomposan akibat besarnya jumlah dikombinasikan dengan pupuk anorganik blotong yang dihasilkan dari limbah seperti pupuk N, $\mathrm{P}$ dan $\mathrm{K}$ dapat pabrik gula. Hal yang biasa dilakukan meningkatkan pertumbuhan dan 
ialah dengan cara hanya membuang kelahan para petani yang berdekatan dengan industri atau dipinggir jalan yang dapat mengganggu lingkungan karena berbau busuk dan berdebu.

Penumpukan blotong dalam jumlah besar akan menjadi salah satu sumber pencemaran lingkungan. Blotong menjadi masalah yang serius bagi pabrik gula dan masyarakat sekitar. Dimusim hujan, tumpukan blotong basah, sehingga menebarkan bau busuk dan mencemari lingkungan. Pabrik gula memindahkannya dari lingkungan pabrik ke lahan masyarakat yang disewa. Hal ini untuk mengurangi tumpukannya yang semakin banyak dalam lingkungan pabrik. Namun, semakin lama banyak masyarakat yang tidak mau lagi lahannya ditempati blotong karena baunya yang busuk. Permasalahan tersebut dapat diatasi dengan memanfaatkan blotong untuk dijadikan pupuk organik melalui pengomposan terlebih dahulu. Langkah pengomposan yang tepat dapat dilakukan dengan cara pengomposan menggunakan teknik "remediation system".

Tujuan makalah ini yaitu untuk memberikan informasi inovasi teknologi dalam penerapan kompos blotong untuk perbaikan kesuburan tanah dan peningkatan produktivitas tanaman tebu.

\section{PEMBAHASAN}

\section{Blotong Tebu}

Tanaman tebu dapat tumbuh di daerah tropika maupun subtropika, karena kemampuan tanaman untuk tumbuh pada berbagai jenis tipe tanah dan ketinggian 0 - $1400 \mathrm{~m}$ di atas permukaan laut (Indrawanto et al., 2010). Tanaman tebu menghasilkan gula sebagai produk utama dan sebagai produk produk samping meliputi daun, bagas, abu, blotong, dan molasse (Kluluq, 2012). Selanjutnya menurut Misran (2005) menyatakan bahwa proses pemanenan tebu dapat menghasilkan limbah berupa daun kering yang disebut klenthekan, pucuk tebu, dan pangkal tebu, sementara dalam proses pengolahan gula akan menghasilkan : gula $( \pm 5 \%)$, ampas tebu/bagas $( \pm 15 \%)$ tete/molasse $( \pm 3 \%)$, sisanya adalah abu, air dan blotong. Blotong atau disebut filter cake/filter press mud (Gambar 1) ialah limbah padat yang berasal dari proses pemurnian nira pabrik gula. Blotong merupakan hasil endapan sebelum dimasak dan dikristalkan menjadi gula pasir yang disaring di rotary vacuum filter. Bentuknya seperti tanah berpasir berwarna hitam, memiliki bau busuk 
jika masih basah. Apabila tidak segera organik yang terdispersi dalam nira tebu dikeringkan maka menimbulkan bau dan bercampur dengan anion-anion busuk yang menyengat (Leovici, 2012). organik dan anorganik (Muhsin, 2011). Blotong mengandung bahan koloid

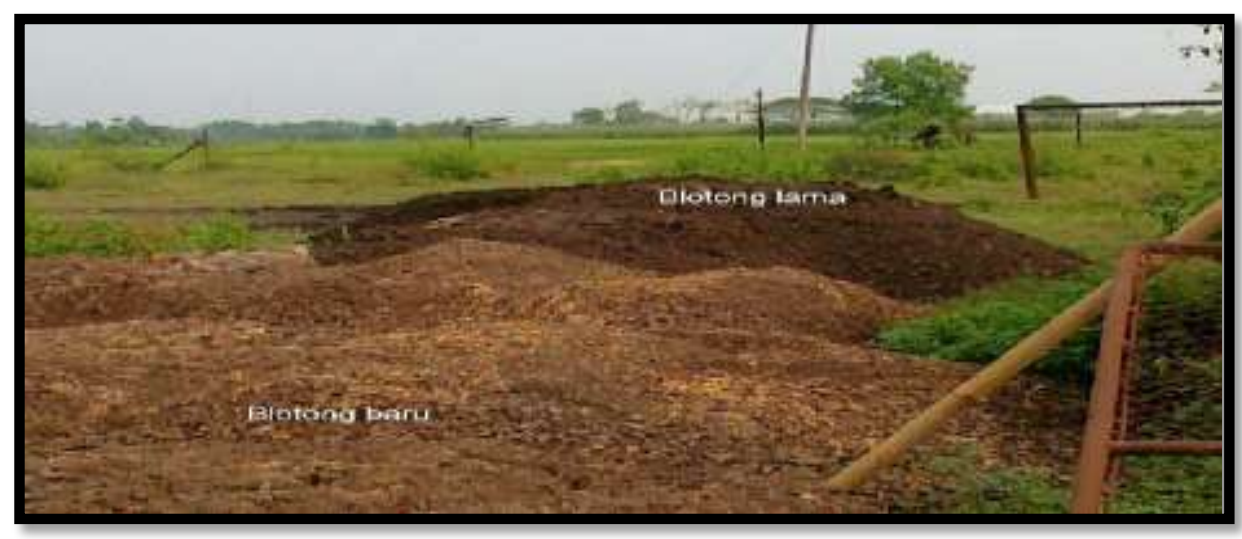

Gambar 1. Blotong Tebu

Kandungan Hara Makro dan Mikro pada Kompos Blotong

Blotong merupakan salah satu

sumber bahan organik dari sisa limbah hasil panen tanaman. Hasil analisis kandungan hara makro dan mikro pada kompos Blotong disajikan pada Tabel 1.

Tabel 1. Kandungan hara makro dan mikro pada kompos blotong

\begin{tabular}{cc}
\hline \hline Komponen (\%) & Nilai (\%) \\
\hline \hline $\mathrm{N}$ & 1,52 \\
$\mathrm{C}-$ Organik & 16 \\
$\mathrm{P}_{2} \mathrm{O}_{5}$ & 7,04 \\
$\mathrm{~K}_{2} \mathrm{O} /$ Kalium & 7,71 \\
$\mathrm{C} / \mathrm{N}$ rasio & 15 \\
$\mathrm{pH}$ & 8,53 \\
$\mathrm{Kadar}$ air & 8,5 \\
$\mathrm{Ca}$ & 1,38 \\
$\mathrm{Abu}$ & 15,3 \\
$\mathrm{Wax} \&$ fat kasar & 5 \\
$\mathrm{MgO}$ & 1,5 \\
$\mathrm{SiO}$ & 10 \\
$\mathrm{Mn}$ & 0,115 \\
$\mathrm{Fe}$ & 0,191 \\
$\mathrm{Na} 2$ & 0,082 \\
$\mathrm{~S}$ & 2,4 \\
$\mathrm{Ca}$ & 4,49 \\
$\mathrm{Cu}$ & 0,01 \\
$\mathrm{Zn}$ & 0,034 \\
\hline \hline
\end{tabular}

Sumber: Puslitbang Gula Jengkol, 2011 
Berdasarkan Tabel 1, menunjukkan bahwa kadar unsur hara makro dan mikro kompos blotong terdiri atas beberapa unsur penting bagi tanaman, antara lain : C-organik (16\%), pH (8.53), N (1.52\%), P (7.04\%), K (7.71\%), Abu (15.3\%), kadar air $(8.5 \%)$ dan unsur-unsur lainnya yang dibutuhkan dalam pertumbuhan tanaman tebu. Disamping itu kompos blotong dapat menyuplai kebutuhan air pada media pertumbuhan tanaman tebu karena memiliki kadar air. Nilai pH pada kompos blotong berarti bahwa kompos blotong diduga dapat membantu menstabilkan nilai $\mathrm{pH}$ tanah. Hal tersebut sesuai untuk memenuhi syarat tumbuh tanaman tebu yang sangat toleran pada kisaran kemasaman tanah $(\mathrm{pH}) 5-8$. Apabila $\mathrm{pH}$ tanah kurang dari 4,5 maka kemasaman tanah menjadi faktor pembatas pertumbuhan tanaman tebu yang dalam beberapa kasus disebabkan oleh pengaruh toksik unsur aluminium $(\mathrm{Al})$ bebas.

Selain kadar air dan nilai $\mathrm{pH}$, kandungan $\mathrm{C}$ dan $\mathrm{N}$ pada kompos blotong menunjukkan nilainya yang cukup rendah namun memberikan kontribusi perbaikan sifat fisika dan biologi tanah serta memberikan tambahan unsur hara ke dalam media tanah yang digunakan. Tanah pertanian yang baik mengandung perbandingan unsur $\mathrm{C}$ dan $\mathrm{N}$ yang seimbang dengan keseimbangan yang baik mempunyai kandungan $\mathrm{C}$ sebesar $10 \%$, sedangkan kandungan $\mathrm{N}$ sebesar $12 \%$. Semakin rendah nilai $\mathrm{C} / \mathrm{N}$ maka akan semakin mudah untuk melepaskan unsur hara. Kompos blotong sangat berguna dalam usaha memperbaiki sifat fisik tanah, sehingga daya menahan airnya meningkat. Tiap ton blotong berkadar air $70 \%$ mengandung hara setara dengan 28 $\mathrm{kg}$ ZA, $22 \mathrm{~kg}$ TSP dan $1 \mathrm{~kg} \mathrm{KCl}$. Hara tersebut mengandung 5,88 $\mathrm{kg} \mathrm{N}, 9,9 \mathrm{~kg} \mathrm{P}$ dan 0,6 kg K (Leovici, 2012).

\section{Potensi Kompos Blotong Tebu sebagai Bahan Organik}

Secara umum bentuk dari blotong berupa serpihan serat-serat tebu yang mempunyai komposisi bahan organik, $\mathrm{N}$ total, $\mathrm{C} / \mathrm{N}, \mathrm{CaO}, \mathrm{MgO}, \mathrm{P}, \mathrm{K}$ dan $\mathrm{Si}$ (Soemarno, 2011). Komposisi setiap blotong sedikit berbeda antara satu dengan yang lain, hal ini disebabkan beberapa keadaan yang berbeda seperti varietas tebu, tanah tempat tumbuh tebu, efisiensi penggilingan dan cara pemurnian dalam pabrik (Elykurniati, 2009).

Persentase blotong cukup tinggi yaitu $9-18 \%$ dari tebu basah dan sangat cepat terdekomposisi menjadi kompos untuk bahan organik (Leovici, 2012). 
Komposisi blotong terdiri dari sabut, wax dan fat kasar, protein kasar, gula, total abu, $\mathrm{SiO}_{2}, \mathrm{CaO}, \mathrm{P}_{2} \mathrm{O}_{5}$ dan $\mathrm{MgO}$ (Muhsin, 2011). Komposisi ini berbeda persentasenya dari satu Pabrik Gula (PG) dengan PG lainnya, bergantung pada pola produkasi dan asal tebu. Kompos blotong dengan komposisi tersebut cukup baik untuk dimanfaatkan menjadi pupuk organik.

Blotong memiliki potensi untuk dijadikan pupuk organik, karena disamping sebagai sumber hara yang cukup lengkap juga dapat membantu memperbaiki sifat-sifat fisik, kimia, dan biologi tanah, namun blotong harus dikomposkan terlebih dahulu sebelum digunakan sebagai pupuk organik tanaman tebu (Soemarno, 2011). Umumnya kompos dari blotong mengandung hara $\mathrm{N}$, $\mathrm{P}_{2} \mathrm{O}_{5}$ dan $\mathrm{K}_{2} \mathrm{O}$ masing-masing sekitar 1$1,5 \%, 1,5-2 \%$ dan $0,6-1 \%$.

Bahan organik sangat bermanfaat bagi peningkatan produksi pertanian baik secara kualitas maupun kuantitas, mengurangi pencemaran lingkungan dan meningkatkan kualitas lahan secara berkelanjutan. Penggunaan pupuk organik dalam jangka panjang dapat meningkatkan produktivitas lahan dan dapat mencegah degradasi lahan (Muhsin, 2011).
Manfaat yang penting ialah dapat memperbaiki sifat fisik tanah di areal perkebunan tebu, khususnya meningkatkan kapasitas menahan air, menurunkan laju pencucian hara, memperbaiki drainase tanah dan meningkatkan ketersediaan $\mathrm{P}$ dalam tanah (Soemarno, 2011). Disamping itu blotong dapat meningkatkan jumlah ruang pori tanah, berat isi tanah dan memperbesar jumlah air tersedia dalam tanah (Muhsin, 2011).

Pemberian bahan organik ke dalam tanah dapat memperbaiki sifat fisik, biologi dan kimia tanah. Peran bahan organik terhadap sifat fisik tanah diantaranya merangsang granulasi, memperbaiki aerasi tanah dan meningkatkan kemampuan menahan air. Peran bahan organik terhadap sifat biologi tanah adalah meningkatkan aktivitas mikroorganisme yang berperan pada fiksasi nitrogen dan transfer hara tertentu seperti N, P dan S. Peran bahan organik terhadap sifat kimia tanah adalah meningkatkan kapasitas tukar kation sehingga dapat mempengaruhi serapan hara oleh tanaman (Soemarno, 2011). 


\section{Inovasi Teknologi Pemanfaatan Kompos Blotong pada Tanaman Tebu}

Berdasarkan studi literatur menunjukkan bahwa penggunaan pupuk anorganik meningkat, tetapi peningkatannya tidak diikuti secara proporsional dengan peningkatan produksi. Hal ini berarti telah terjadi penurunan efisiensi penggunaan pupuk sehingga perlu inovasi baru penggunaan pupuk yang lebih efisien. Untuk dapat meningkatkan efisiensi dan efektivitas pupuk dapat dilakukan dengan cara penambahan pupuk organik yaitu kompos blotong. Penggunaan pupuk kompos blotong dapat menurunkan penggunaan pupuk anorganik. Kombinasi kompos blotong dengan pupuk anorganik merupakan inovasi pemupukan yang dapat digunakan untuk meningkatkan produksi tebu. Upaya peningkatan produksi tebu sangat tergantung pada aplikasi pupuk anorganik dan pupuk organik. Dalam upaya mewujudkan pertanian berkelanjutan, maka aplikasi pemupukan sebaiknya tidak hanya menggunakan pupuk anorganik, namun dikombinasikan dengan pupuk organik sehingga dapat menurunkan penggunaan atau mengurangi kebutuhan pupuk anorganik secara perlahan (Gujja et al., 2009).
Kompos blotong dapat memperbaiki struktur tanah dengan meningkatkan kandungan bahan organik tanah dan akan meningkatkan kamampuan tanah untuk mempertahankan kandungan air tanah. Aktivitas mikroba tanah yang bermanfaat bagi tanaman akan meningkat dengan penambahan kompos. Aktivitas mikroba ini membantu tanaman untuk menyerap unsur hara dari tanah, selain itu dapat membantu tanaman menghadapi serangan penyakit (Soemarno, 2011). Kompos blotong juga dapat memperbaiki sifat fisik tanah di areal perkebunan tebu, khususnya meningkatkan kapasitas menahan air, menurunkan laju pencucian hara, memperbaiki drainase tanah, dan menetralisir pengaruh $\mathrm{Al}$ sehingga ketersediaan $\mathrm{P}$ dalam tanah lebih tersedia (Leovici, 2012).

Manfaat kompos ditinjau dari beberapa aspek, yaitu : a) Ekonomi : menghemat biaya untuk transportasi dan penimbunan limbah, mengurangi volume/ukuran limbah, memiliki nilai jual yang lebih tinggi dari pada bahan asalnya. b) Lingkungan : mengurangi polusi udara karena pembakaran limbah dan pelepasan gas metana dari sampah organik yang membusuk akibat bakteri metanogen ditempat pembuangan sampah, 
mengurangi kebutuhan lahan untuk melarutkan tersebut ialah mikroba penimbunan. c) Tanah/tanaman : (Leovici, 2012).

meningkatkan kesuburan tanah, Menurut Muhsin (2011) bahwa memperbaiki struktur dan karakteristik kompos yang bersumber dari ampas tebu tanah, meningkatkan kapasitas penyerapan dan diaplikasikan pada tanaman tebu, air oleh tanah, meningkatkan aktivitas dapat meningkatkan penyerapan nitrogen mikroba tanah, menyediakan hormon bagi secara signifikan setelah 3 bulan tanaman, meningkatkan ketersediaan hara pengaplikasian dibandingkan kontrol di dalam tanah. Beberapa studi telah (tanpa kompos), namun tidak ada dilakukan terkait manfaat kompos bagi peningkatan yang berarti terhadap tanah dan pertumbuhan tanaman. Kompos memberikan peningkatan kadar kalium tersedia dalam tanah lebih tinggi dari pada kalium yang disediakan dari pupuk NPK anorganik. Pemberian kompos akan menambah bahan organik tanah sehingga meningkatkan kapasitas tukar kation tanah dan mempengaruhi serapan hara oleh tanah, walaupun tanah dalam keadaan masam (Soemarno, 2011).

Pemanfaatan kompos blotong diharapkan mampu membantu mengatasi masalah kelangkaan pupuk kimia dan sekaligus mengatasi masalah pencemaran lingkungan. Kompos blotong mengandung beberapa mikroba, yaitu Celulotic bacteria, Pseudomonas, Bacyllus, dan Lactobacyllus. Bakteri tersebut ada yang berfungsi melarutkan fosfat. Seperti diketahui, fosfat jika dipakai untuk pupuk harus dalam keadaan terlarut, dan yang penyerapan fosfor, kalium dan sulfur. Selanjutnya penggunaan kompos bagasse dengan pupuk anorganik secara bersamaan dapat meningkatkan pertumbuhan tanaman tebu (Soemarno, 2011). Selanjutnya unsur fosfat sangat penting dalam peningkatan rendemen tebu, karena berperan dalam proses fotosintesa pada daun tanaman sampai sintesa sukrosa dalam batang tebu, sementara menurut Leovici (2012) bahwa keefektifan bakteri pelarut fosfat dapat ditingkatkan dengan cara pemberian kompos blotong. Bakteri akan menggunakan bahan organik dari kompos tersebut sebagai sumber energy untuk mendukung perkembangbiakan dan peningkatan aktivitasnya. Bakteri pelarut fosfat tersebar pada daerah perakaran (rizofer) karena terdapatnya eksudat akar berupa senyawa karbohidrat dan senyawa 
nitrogen, sehingga berdampak pada tinggi 26,5 ton/ha dan 8,1 ton/ha

peningkatan populasi bakteri. Komposisi dan jumlah senyawa yang diekskresikan akar menentukan jumlah dan jenis bakteri. Beberapa bakteri tanah yang hidup disekitar akar (rizofer) mampu mengekskresikan asam-asam organik serta membentuk kelat dengan ion $\mathrm{Ca}^{2+}, \mathrm{Mg}^{2+}$, $\mathrm{Fe}^{3+}$ dan $\mathrm{Al}^{3+}$ sehingga mampu membebaskan ion fosfat terikat menjadi fosfat yang dapat diserap oleh tanaman. Kelompok bakteri ini disebut bakteri pelarut atau pembebas fosfat (Soemarno, 2011).

\section{Pemberian blotong dapat meningkatkan kandungan hara dalam tanah terutama unsur $\mathrm{N}, \mathrm{P}$, dan $\mathrm{Ca}$ serta unsur mikro lainnya. Peranan kompos blotong pada tanah dapat dipastikan sama} dengan peranan kompos atau pupuk organik lainnya dalam memperbaiki sifatsifat kesuburan tanah, sehingga secara umum kompos blotong dapat meningkatkan produktivitas tebu. Pemberian kompos blotong dan kompos ampas pada lahan tebu di pabrik gula Cintamanis Palembang, masing-masing dengan takaran 30 ton/ha mampu meningkatkan bobot tebu. Bobot tebu yang diberikan pupuk kompos ini pada tanaman pertama, berturut-turut lebih dibandingkan dengan kontrol (Leovici, 2012).

Penelitian yang dilakukan oleh Mulyadi (2000) menunjukkan bahwa pemberian blotong nyata meningkatkan tinggi tanaman, diameter batang, jumlah tanaman/rumpun, dan bobot kering tebu berumur 4 bulan yang ditanam di tanah kandiudoxs. Dosis efektif yang digunakan adalah 40 ton/ha, ditandai dengan peningkatan tinggi tanaman 58\%, diameter batang sebesar $31 \%$, jumlah tanaman/rumpun sebesar $25 \%$, dan bobot kering tanaman bagian atas sebesar $225 \%$ dibanding perlakuan tanpa blotong. Sedangkan berdasarkan penelitian Parinduri (2005), dosis blotong 20 ton/ha dapat meningkatkan jumlah anakan tebu $11,02 \%$, bobot kering tajuk 8,43\%, bobot kering tanaman 5,33\%, bobot kering dan luas daun 20,43\% dibandingkan dengan perlakuan pemupukan anorganik $\mathrm{N}, \mathrm{P}, \mathrm{K}$ dan ZA.

Berdasarkan penelitian yang dilakukan oleh Purwono et al. (2011), menunjukkan bahwa dosis blotong nyata mempengaruhi rendemen tebu. Apabila dosis kompos dikaitkan dengan frekuensi penyiraman, keduanya saling berinteraksi dalam mempengaruhi rendemen tebu. Ada 
Muh. Afif Juradi : Inovasi Teknologi Penerapan Kompos Blotong untuk Perbaikan Kesuburan Tanah dan Peningkatan Produktivitas Tanaman Tebu

korelasi yang signifikan antara Brix dan mengkombinasikan pupuk anorganik. hasil gula. Kandungan sari tebu memiliki Menurut Gujja et. al., (2009) bahwa cara kontribusi yang besar terhadap hasil gula. pengaplikasian kompos blotong pada Metode Aplikasi Kompos Blotong tanaman tebu ialah saat sebelum tanam dalam Pemupukan Tanaman Tebu

Metode atau cara pengaplikasian pada juringan/furrow pada pertanaman kompos blotong dilakukan dengan tebu pertama/bukaan baru (Plant Cane).

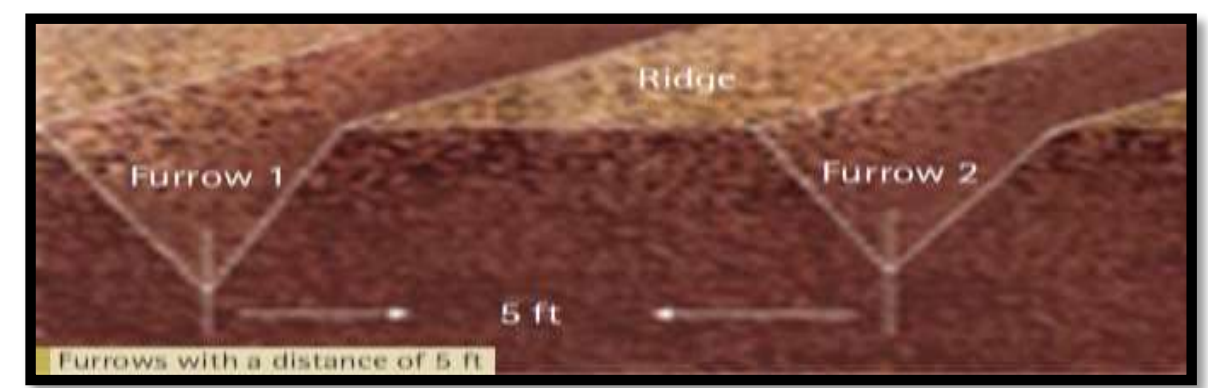

Sumber: Gujja et al., 2009

Gambar 2. Juringan untuk meletakkan Kompos Blotong

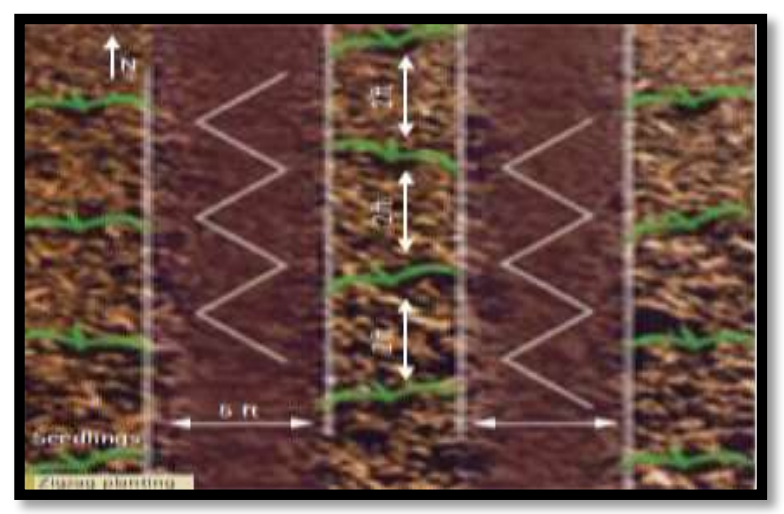

Sumber: Gujja et al., 2009

Gambar 3 Posisi Kompos Blotong jika menggunakan Bibit Budch 


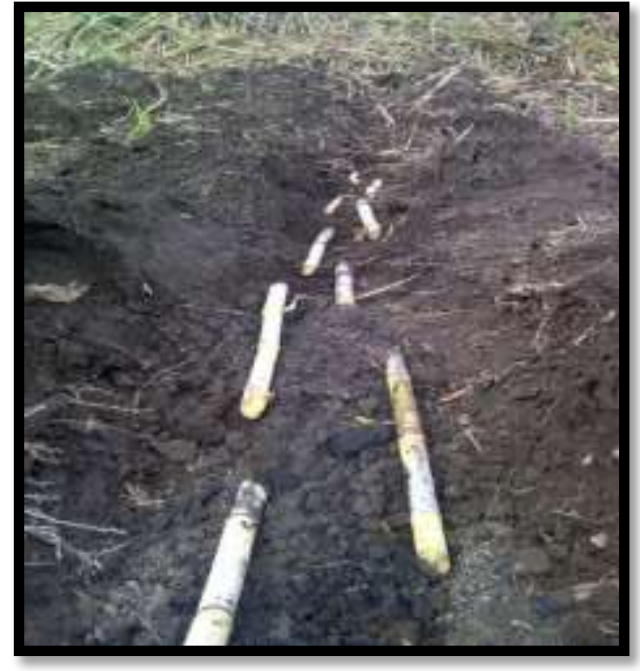

Sumber: Gujja et al., 2009

Gambar 4 Contoh pemberian Blotong saat Penanaman Bagal

Rekayasa Teknik Fermentasi Kompos Blotong

Kompos blotong dapat difermentasi melalui suatu rekayasa teknik fermentasi atau pengomposan sederhana dengan remediation system (sistem pengkondisian media kembali) pada limbah padat industri sangat efisien. Penggunaan bakteri starter yang mengandung jasad renik Nitrobacteriaceae dan Thiobakteriaceae dapat memproduksi unsur nitrogen dan sulfur yang dibutuhkan oleh tanaman tebu. Proses pengomposan sangat cepat, dua kali lebih cepat dibandingkan dengan pengomposan secara konvensional, sehingga produksi dan kualitasnya dapat meningkat. Dapat digunakan dalam bentuk pabrikasi untuk setiap industri yang menghasilkan limbah padat yang bermasalah di lingkungannya.

Teknik ini menggunakan azas-azas teknik fermentasi sederhana yaitu : (1) mengkondisikan media (remediation system) agar mikroba dapat menyesuaikan dengan lingkungan yang baru secara cepat, (2) uji selektivitas jasad renik, (3) fermentasi langsung di dalam karung pengepak, unit-unit material yang relative murah dan dapat dilaksanakan dengan cepat dan mudah sehingga produktivitas kompos blotong tinggi sesuai volume limbah yang dibuang oleh industri pabrik gula (Soemarno, 2011).

Menurut Leovici (2012) bahwa blotong harus dikomposkan terlebih dahulu sebelum digunakan sebagai pupuk organik tanaman tebu. Pengomposan merupakan suatu metode untuk 
mengkonversikan bahan-bahan organik komplek menjadi bahan yang lebih sederhana dengan menggunakan aktivitas mikroba. Pengomposan dapat dilakukan pada kondisi aerobik dan anaerobik. Pengomposan aerobik adalah dekomposisi bahan organik dengan kehadiran oksigen (udara). Produk utama dari metabolis biologi aerobik adalah karbondioksida, air dan panas. Pengomposan anaerobik adalah dekomposisi bahan organik dalam kondisi ketidakhadiran oksigen bebas. Produk akhir metabolis anaerobik adalah metana, karbondioksida, dan senyawa intermediate seperti asam-asam organik dengan berat molekul rendah.

\section{KESIMPULAN}

1. Blotong memiliki potensi sebagai sumber bahan organik dari sisa limbah hasil panen tanaman tebu.

2. Kandungan unsur hara makro dan mikro dalam kompos blotong berperan penting dalam mendukung pertumbuhan tanaman.

3. Aplikasi kompos blotong dalam jangka panjang dapat meningkatkan kesuburan fisik, biologi dan kimia lahan terdegradasi.

4. Aplikasi kombinasi kompos blotong dengan pupuk anorganik dapat menurunkan penggunaan pupuk anorganik.

5. Aplikasi blotong dapat meningkatkan kandungan hara $\mathrm{N}, \mathrm{P}$ dan unsur mikro dalam tanah serta dapat meningkatkan pertumbuhan dan produktivitas tanaman tebu.

\section{DAFTAR PUSTAKA}

Elykurniati.2009. Pemanfaatan Blotong Menjadi Bahan Bakar Cair dan Arang dengan Proses Pirolisis.Laporan Penelitian, Fakultas Teknologi Industri, Universitas Pembangunan Nasional, Veteran. Jawa Timur. p. 1-42

Gujja, B., N. Loganandhan, V. V. Goud., M. Agarwal and S. Dalai. 2009. Sustainable Sugarcane Initiative (SSI) Improving Sugarcane Cultivation. ICRISAT. Andhra Prasesh, India. p. 1-36

Indrawanto, C., Purwono, Siswanto, M. Syakir, dan W. Rumini. 2010. Budi daya dan pascapanen Tebu. Pusat Penelitian dan Pengembangan Perkebunan, Bogor.

Khuluq, A. D. 2012. Potensi Pemanfaatan Limbah Tebu sebagai Pakan Fermentasi Probiotik. Buletin Tanaman Tembakau, Serat \& Minyak Industri. 4(1) : 37-45.Leovici, H. 2012. Pemanfaatan Blotong pada Budidaya Tebu (Saccharum officinarum L.) di Lahan Kering. 
Fakultas Pertanian, Universitas Gadjah Mada, Yogyakarta. p. 1-25

Misran, E. 2005. Industri tebu menuju zero waste industri. Jurnal teknologi proses 4 (2) : 6 - 10 .

Muhsin, A. 2011. Pemanfaatan Limbah Hasil Pengolahan Pabrik Tebu Blotong Menjadi Pupuk Organik. J Industrial Enginering Conference. Fakultas Teknologi Industri, UPN, Yogyakarta. p. 1-9

Mulyadi, M. 2000. Kajian Pemberian Blotong dan Terak Baja pada Tanah Kandiudoxs Pelaihari dalam Upaya Memperbaiki Sifat Kimia Tanah, Serapan N, Si, P, dan S serta Pertumbuhan Tebu. Thesis. Program Pascasarjana, Institut Pertanian Bogor, Bogor.

Parinduri, S. 2005. Respon Tanaman Tebu (Saccharum officinarum L.) terhadap Pemberian Blotong yang diperkaya dengan Bakteri Pelarut
Fosfat dan Azospirillum.Thesis. Program Pascasarjana, Institut Pertanian Bogor, Bogor.

Purwono, D. Sopandie1, S. S. Harjadi1, and B. Mulyanto. 2011. Application of Filter Cake on Growth of Upland Sugarcane. Journal of Agronomy Indonesia 39:79-84

Puslitbang. 2010. Hasil Analisa Kompos Blotong Tebu. Pusat Penelitian Perkebunan Gula Indonesia. Jengkol.

Putri, A. D. Sudiarso dan Islami, T. 2013. Pengaruh Komposisi Media Tanam pada Teknik Budchip Tiga Varietas Tebu (Saccharum officinarum L.). Jurnal Produksi Tanaman. 1 (1) : 16 -23 .

Soemarno. 2011. Strategi Peningkatan Rendemen Tebu. Pascasarjana Universitas Brawijaya. Malang. p. 41-46, 53-59. 